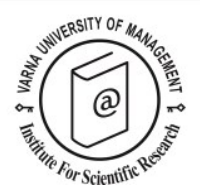

\title{
Surfing Tourism Plan: Madeira Island Case Study
}

\author{
João T. Lopes ${ }^{1 *}$ and Pedro Bicudo ${ }^{2}$
}

Received: 15/06/2015 Accepted: 21/11/2016

\footnotetext{
1 SOS- Salvem O Surf, Environmental NGO, Rua da Feitoria, Pavilhão Desportivo dos Lombos, Espaço 19, 2775-568 Carcavelos. Email: joaotlopes@gmail.com

2 SOS- Salvem O Surf, Environmental NGO, Rua da Feitoria, Pavilhão Desportivo dos Lombos, Espaço 19, 2775-568 Carcavelos. CFTP, Departamento de Física, Instituto Superior Técnico, Universidade de Lisboa

*

Corresponding author
}

\begin{abstract}
Surfing tourism provides a global business opportunity and forms part of the billionaire industry of adventure tourism. Surfing has successfully attracted participants willing to search for locations and unique adventure experiences, looking for surfing perfect conditions. It becomes essential to understand how surfers list and compare surfing destinations. In Portugal, surfing has been growing exponentially over the last decades not only as a sport, but also as a social and economic activity. However, surf spots have been damaged due to coastal constructions. This study aims to identify characteristics of Madeira's surf spots and surf industry services. SOS - Salvem o Surf practical model was used, which is based on geography, geology and meteorology aspects, and support infrastructure and services. We also discuss recovering surf spots which lost part of their world class quality, due to not including surfing in coastal management in the past. We consider surf spots improvement for surf tourists and beginners surfers, with the use of Multi-Purpose Reefs. Our results also suggest that surfing provides successfully alternatives, limiting the phenomenon of seasonality. This confirms that Madeira Island possesses several surf spots, with diverse degrees of difficulty, allowing surfing from beginner to advanced levels. This study provides a better understanding of surf tourist's choice patterns, which benefits both surfers and the tourism industry.
\end{abstract}

(C) 2017 Varna University of Management. All rights reserved

Keywords: Coastline Management; Environmental Policies; Surfing Tourism; Sustainable Development.

Citation: Lopes, J., P. Bicudo (2017) Surfing Tourism Plan: Madeira Island Case Study. European Journal of Tourism Research 16, pp. 45-56

\section{Introduction}

Surf tourism provides a global business opportunity and makes part of the multibillionaire industry of adventure and sport tourism. In some of the most popular touristic destinations such as Hawaii, Australia and Indonesia, surf tourism accounts for a substantial portion of touristic income, and has been estimated globally to be around 10 million dollars annually by the year 2002 (Buckley, 2002), while indirectly contributing to the development of other activities of local economies. With an estimated 10 million surfers in 120 countries and an industry worth 
in excess of 6 billion dollars with estimates of this increasing to 13 billion by 2017 , surfing as with any big business has a significant impact both globally and locally (Borne, 2014). Leal (2007) refers that the emergence of new and more sophisticated sports practices associated with the outdoors, and especially those practiced in the ocean and coastline, has contributed positively to the increase of tourists searching for adventure and recreation. Surfing is a sport associated with the ocean environment which has most successfully attracted participants willing to search the globe for locations and unique adventure experience, looking for the perfect conditions concerning the quality of the waves and surf spots (Fluker, 2003).

Surf tourism includes not only surfers but also other target population, such as spectators, journalist, companions, and entire families. Nevertheless, and taking into account the demands of this phenomenon, it becomes essential to obtain information of how different groups of surfers list and compare the diversity of several surfing destinations. This type of tourism is a new business opportunity worldwide (has been estimated globally to be around 13 billion Euros (Buckley, 2002), being part of the multi-billionaire industry of Adventure and Sports Tourism. Since the regional tourism sector is 20 to 40 per cent of the Gross Domestic Product (GDP) of Madeira Region (Portugal) and is actually responsible, directly or indirectly, for 15 per cent of all jobs in Madeira Island (Lopes, 2008).

In Europe, and especially in Portugal, surfing being considered not only as a sport, but also as an economic activity, has shown a very significant development in the last decade. This is reflected not only in increasing the number of practitioners, as well as to increase the economic benefits associated with the market that involves this sport (such as the sale of sports equipment, rental equipment, the establishment of surf schools and surf camps specific accommodation for surfers, families and supporters, or to raise sponsorship for conducting competitions). It is estimated that in Portugal the surfing industry can move about 300 million a year (Ferrony, 2013). Based on this, the preservation or the destruction of surf spots can be quantified in terms of their economic impact, which reflects the national panorama, but especially the local communities' scenario.

National examples like the regions of Ericeira municipality and Peniche municipality and recently Nazaré municipality are required in this analysis: the position of local authorities against the importance of surfing has changed and has proven its value in the development of the local economy (Horta \& Bicudo, 2009; Ferrony, 2013; SOS, 2014). The same authors', stating that corroborates the international panorama, the surfing market represents a turnover estimated at 11 billion Euros (from 2005 to 2006). This overall figure, the European market grossed 1.48 billion Euros of which 1.1 billion of Euros are allocated to the profits of companies based in the French region of Aquitaine. In the Portuguese territory, for five years now, the number of surfers stood between 50 and 70 thousand (who practice surfing at least once a week). Currently, according to data released by the Federation of Surf Portugal, there are over 200,000 practitioners, the second most practiced sport in the country after soccer.

Considering this in terms of the economic impact of the surfing industry, there are mainly two methods of analysis: the total profits of various companies related to surfing and supported by practitioners of the sport cost. For this factor, it should be noted that a regular practitioner of this sport spends approximately between 2000 to 3000 Euros per year in sports equipment and travel. Adding to this figure the 200 to 500 thousand Euros profit of surfing proceeding from international competitions (which can easily reach one million Euros), equipment and stores reached a total value of 150 to 200 million Euros representative of the economic gains of surfing in Portugal (Horta, 2009; Bicudo, 2009).

Based on this panorama the main aim of this study is to analyse the regional strategies of surfing as a touristic product in Madeira Island, based on the natural resources and contributing for the enhancement of planning and implementation strategies of tourism marketing at regional level. This study is 
organized in several sections. In section 2, we detail our methodology, in section 3 we show the main results of our work. Finally we conclude and do the study discussion and possible recommendations in section 4 .

\section{Methodology}

Taking in account that the objective of this research is to analyse the Madeira Island's strategies of surfing as a touristic product, based on the natural resources and attributes, and serving as a base for the enhancement of planning and implementation strategies of tourism marketing at regional level. To achieve this goal, we started to identify characteristics of Madeira Island's surf spots, as well as identify the strong points that this region can offer when it comes to surf tourism destination decision (surf tourism industry services). It is essential to find out which attributes can a surf spot create as a competitive advantage in the adventure tourism industry compared to its rival destinations, which are the best surf spots on the island, its locations, and which attributes are associated to them. Another issue we focus in this study is what kind of improvement can be done to make Madeira Region a sustainable top rated surfing destination.

To accomplish these objectives, we divided the present study in two major phases: 1) The Features and Capabilities of each surf spots, and 2) The Perspectives of Local Surfers about Surfing as Tourist Product in Madeira Island.

In the first phase, to identify the strongest points and characteristics of the surf spots / waves and natural potential of Madeira Island, we used direct observation (recorded images photos and videos - complemented with previous studies (Freitas, 2005; Sutherland, 2007; Lopes, 2008); photography report, and used the practical model of surf spot characterization of the Environment NGO SOS - Salvem O Surf adapted to the reality of the conditions of the island in the years 2007, 2011 and 2014. This model is based on aspects such as geography, geology and meteorology. In order to accomplish this issue, we assessed the surf spots' characteristics (the type of wave; the quality of wave; the seafloor type; the wave direction; the swell direction; the best tide; the best wind direction; the consistency, as well as the best season to surf each surf spot); the surfers experience for each surf spot (in a good day; in a average day and crowd population); the surf spots facilities and its access (the support infrastructure; if there are any surf schools and / or any surf camps near the surf spot; and the type of access to the surf spot); and finally the surf spots possible interventions based on touristic aspects (touristic interest; specifications of particular surf spots as well as possible interventions to improve quality of it).

In the second phase of the study, and to give more strength and to complement the data collected in the field, the most experienced local surfers (with more than ten years of surfing), in a total of twelve, were interviewed. These surveys were able to confirm previous findings and supported the strong and weak features of regional surfing as a tourist product. The variables evaluated were: surfing particularities and attributes in Madeira Island (the current panorama of surfing in Madeira Region; the main strengths and weaknesses of surfing in the island; the most important characteristics related with surfing in Madeira Island; the potential of surfing for tourist services); the most chosen surf spots and its attributes (Madeira Island natural conditions to surfing; the best surf spots and most frequented; the existence of facilities and support infrastructure on the local surf spots); as well as touristic promotion of surfing in Madeira Island (assessment of the promotion of surfing as a tourism product; sports events national and international surf contests / competitions - as tourism promotion engines).

\section{Results}

Over the past nine years, we were able to perform several visits (2007, 2011, and 2014) to all surf spots (total of 36) in Madeira Island, having all the parameters been registered on a data basis. In addition to this, we also performed surveys to the most experienced local surfers who confirmed our data and added value information to the study.

Madeira Island has several quality surf spots in its coastline, with many attributes such as ideal wave climatology, air and water temperature and an extensive multi-oriented shoreline, allowing surf practice all year long and in 
remote coastal places with low population density. This contributes to the diminution of the seasonal phenomenon and to the decentralization of the tourism offer in the Region, helping to meet some of the goals of the regional tourism plan (Lopes, 2008).

Overall, the regional surf spots studied have very interesting and quite different features that classify the sport according to specific skill levels for various degrees of difficulty for practitioners (see Tables 1 and 2). There are only two surf spots with low difficulty level (for beginners - all surfers) and for tourists seeking recreation and the first experience, located in Porto da Cruz (Machico municipality). On the other hand, there are other surf spots that are extremely popular, because the waves are very consistent and of considerable size, and have a higher frequency which make it possible to surf during all year. One of the mainly important and advantageous features of the most required surf spots, considering the seasonality itself, is the beaches accessibility and safe conditions. This is confirmed by our survey among the most experienced local surfers.

However, the characteristics of accessibility and security are not present on all beaches / surf spots (see Table 2 and 3 ). The surf spots chosen by local surfers that deserve special attention (taking into account the challenge, the adventure and the consistency of the waves), are: the wave of Paul do Mar (Calheta municipality), the wave of Jardim do Mar (Calheta municipality), the wave of Ribeira da Janela (Porto Moniz municipality), and the wave of Ponta Pequena (Calheta municipality), and then is the wave of Lugar de Baixo (Ponta do Sol municipality).

In the mid 90's, with a local surfing community of already from 25 to 30 surfers, and with the first surfing contests, the sport gained a new dimension. Simultaneously, national and international surfers choose to settle in the region, all searching for the famous Madeira Island waves. Currently, it is estimated that between federated surfers and non-federated surfers there is a local community of about 200 to 250 surfers. Some of these are not full-time residents; however choose Madeira Island for the purchase of a second home given the excellent conditions for surfing.

Over the past 15 years, the local surfing industry in Madeira Island has increased considerably. The increase in the number of practitioners brought new business such as surf camps, surf schools, surf shops, and also new surfboards factories. Parallel to the increase of the infrastructure mentioned above, the competition scenario also arises.

Madeira Island's coastline allows the practice to all the surfers, independently of their level (see Table 2), since there are some surf spots which have low difficult level, and with easy access to the younger, or less experienced surfers, and because there are nowadays 8 surf schools in the Region (see Table 3).

In general, most of the surf spots are located close to villages and with a good access and supportive infrastructures. However, the construction of some coastal structures has damaged some surf spots, reducing their quality and making them more dangerous for surfing, specially to the less experienced surfers.

Another issue is the marketing promotion and the tourism importance and positioning of this sport in this region. This is quite interesting, because in the early 2000 there were a few companies and enterprises, most of them private ones, which included surfing as an important tourist segment. On the other hand, the regional government did not invest or bet so much on it, having a low promotion from the administrative organs. That is the reason why it was suggested a marketing strategy from these organs about this type of tourism. Contrarily, in the actual panorama, the department of tourism is trying to captivate this "new form" of tourism, betting in a much stronger image of this sport, as well as trying to rehabilitate some of the main surf spots damaged in the past with the consultation help of NGO SOS - Save Our Surf.

In what concerns the typical accommodation of this type of tourism, by the year 2003 there were only two surf camps concentrated in Jardim do Mar (Calheta municipality) in the 
Table 1. The surf spots characteristics

\begin{tabular}{|c|c|c|c|c|c|c|c|c|c|}
\hline Surf Spot & Municipality & $\begin{array}{l}\text { Qua } \\
\text { lity } \\
1-5\end{array}$ & $\begin{array}{l}\text { Sea } \\
\text { Floor } \\
\text { Type }\end{array}$ & $\begin{array}{l}\text { Wave } \\
\text { Direction }\end{array}$ & $\begin{array}{l}\text { Swell } \\
\text { Direction }\end{array}$ & Best Tide & $\begin{array}{l}\text { Wind } \\
\text { Direction }\end{array}$ & $\begin{array}{l}\text { Consis- } \\
\text { tency }\end{array}$ & $\begin{array}{l}\text { Best } \\
\text { Season }\end{array}$ \\
\hline Praia Formosa & Funchal & 3 & $\begin{array}{l}\text { Sand and } \\
\text { Rocks }\end{array}$ & Right Hand & $S-S W-W$ & Low - Mid & $N-N E$ & $\begin{array}{l}\text { Poor to } \\
\text { Average }\end{array}$ & Dec-Apr \\
\hline $\begin{array}{l}\text { Praia dos } \\
\text { Namorados }\end{array}$ & Funchal & 2 & $\begin{array}{l}\text { Sand and } \\
\text { Rocks }\end{array}$ & $\begin{array}{l}\text { Left and } \\
\text { Right Hand }\end{array}$ & SE - S - SW & Low - Mid & $N-N E$ & Poor & Dec - Feb \\
\hline $\begin{array}{l}\text { Pizo/ Ribeira dos } \\
\text { Socorridos }\end{array}$ & $\begin{array}{l}\text { Câmara de } \\
\text { Lobos }\end{array}$ & 3 & Rocks & Right Hand & $S-S W-W$ & Mid & $N-N E$ & $\begin{array}{l}\text { Poor to } \\
\text { Average }\end{array}$ & Dec-Apr \\
\hline Cabo Girão & $\begin{array}{l}\text { Câmara de } \\
\text { Lobos }\end{array}$ & 5 & Rocks & Right Hand & SW -W-NW & Mid - High & $N-N E$ & Average & Oct - Apr \\
\hline Fajã dos Padres & Ribeira Brava & 4 & Rocks & Right Hand & SW-W -NW & Mid - High & $N-N E$ & $\begin{array}{l}\text { Poor to } \\
\text { Average }\end{array}$ & Oct - Apr \\
\hline Lugar de Baixo & Ponta do Sol & 5 & Rocks & Right Hand & SW-W-NW & Mid - High & $N-N E$ & Average & Oct - May \\
\hline Madalena do Mar & Ponta do Sol & 3 & $\begin{array}{l}\text { Sand and } \\
\text { Rocks }\end{array}$ & $\begin{array}{l}\text { Left and } \\
\text { Right Hand }\end{array}$ & SW-W-NW & All Tides & $N-N E-E$ & $\begin{array}{l}\text { Poor to } \\
\text { Average }\end{array}$ & Oct - May \\
\hline Jardim do Mar & Calheta & 5 & Rocks & Right Hand & W-NW & Low - Mid & $N-N E-E$ & $\begin{array}{l}\text { Average } \\
\text { to High }\end{array}$ & Sep-May \\
\hline Ponta Pequena & Calheta & 5 & Rocks & Right Hand & W - NW & Low - Mid & $N-N E-E$ & $\begin{array}{l}\text { Average } \\
\text { to High }\end{array}$ & Sep - May \\
\hline Paúl do Mar & Calheta & 5 & Rocks & Right Hand & W - NW & Low - Mid & $N-N E-E$ & $\begin{array}{l}\text { Average } \\
\text { to High }\end{array}$ & Sep-May \\
\hline $\begin{array}{l}\text { Fajã da Galinhas } \\
\text { Ponta do Pargo }\end{array}$ & $\begin{array}{l}\text { Calheta } \\
\text { Calheta }\end{array}$ & $\begin{array}{l}5 \\
5\end{array}$ & $\begin{array}{l}\text { Rocks } \\
\text { Rocks }\end{array}$ & $\begin{array}{l}\text { Right Hand } \\
\text { Right Hand }\end{array}$ & $\begin{array}{l}N-N W \\
N-N W\end{array}$ & $\begin{array}{l}\text { Low } \\
\text { Low }\end{array}$ & $\begin{array}{l}N E-E \\
E-N E\end{array}$ & $\begin{array}{l}\text { High } \\
\text { High }\end{array}$ & $\begin{array}{l}\text { All year } \\
\text { All year }\end{array}$ \\
\hline $\begin{array}{l}\text { Praia das } \\
\text { Achadas da Cruz }\end{array}$ & Porto Moniz & 5 & Rocks & Right Hand & $N-N W$ & Mid - High & E - SE & High & All year \\
\hline Ponta do Tristão & Porto Moniz & 4 & Rocks & Right Hand & $N-N W$ & Low - Mid & E - SE & High & All year \\
\hline $\begin{array}{l}\text { Lage das Piscinas } \\
\text { do Porto Moniz }\end{array}$ & Porto Moniz & 3 & $\begin{array}{l}\text { Rocks } \\
\text { and Reef }\end{array}$ & $\begin{array}{l}\text { Left and } \\
\text { Right Hand }\end{array}$ & $N-N W$ & Mid & S - SE & High & All year \\
\hline Ribeira da Janela & Porto Moniz & 5 & Rocks & Left Hand & $N-N W$ & Low - Mid & $E-S E-S$ & High & Sep - May \\
\hline $\begin{array}{l}\text { Fajã das } \\
\text { Contreiras }\end{array}$ & Porto Moniz & 5 & Rocks & Left Hand & $N-N W$ & Mid - High & $E-S E-S$ & High & Sep - May \\
\hline $\begin{array}{l}\text { Envelopes } \\
\text { (Ribeira Funda) }\end{array}$ & Porto Moniz & 3 & $\begin{array}{l}\text { Sand and } \\
\text { Rocks }\end{array}$ & Left Hand & $N-N W$ & Mid & $E-S E-S$ & $\begin{array}{l}\text { Average } \\
\text { to } \\
\text { High }\end{array}$ & Oct - Mar \\
\hline $\begin{array}{l}\text { Praia da Jamaica } \\
\text { (Seixal) }\end{array}$ & Porto Moniz & 4 & $\begin{array}{l}\text { Sand and } \\
\text { Rocks }\end{array}$ & $\begin{array}{l}\text { Left and } \\
\text { Right Hand }\end{array}$ & $N-N W$ & Mid - High & $E-S E-S$ & $\begin{array}{l}\text { Average } \\
\text { to High }\end{array}$ & Oct - Mar \\
\hline $\begin{array}{l}\text { Esquerdas de São } \\
\text { Vicente }\end{array}$ & São Vicente & 5 & $\begin{array}{l}\text { Sand and } \\
\text { Rocks }\end{array}$ & Left Hand & $N-N W$ & All Tides & $\begin{array}{l}\text { SW - S - } \\
\text { SE }\end{array}$ & High & All year \\
\hline $\begin{array}{l}\text { Direitas de São } \\
\text { Vicente }\end{array}$ & São Vicente & 4 & $\begin{array}{l}\text { Sand and } \\
\text { Rocks }\end{array}$ & Right Hand & $\mathrm{N}-\mathrm{NW}-\mathrm{NE}$ & Low - Mid & $\begin{array}{l}\text { SW - S - } \\
\text { SE }\end{array}$ & $\begin{array}{l}\text { Average } \\
\text { to High }\end{array}$ & All year \\
\hline $\begin{array}{l}\text { Fajã da Areia } \\
\text { (Baía dos Juncos) }\end{array}$ & São Vicente & 5 & $\begin{array}{l}\text { Rocks } \\
\text { and Reef }\end{array}$ & $\begin{array}{l}\text { Left and } \\
\text { Right Hand }\end{array}$ & $\mathrm{N}-\mathrm{NW}-\mathrm{NE}$ & Low - Mid & $\begin{array}{l}\text { SW - S - } \\
\text { SE }\end{array}$ & High & All year \\
\hline Pico do Manny & São Vicente & 4 & Rocks & $\begin{array}{l}\text { Left and } \\
\text { Right Hand }\end{array}$ & $\mathrm{N}-\mathrm{NW}-\mathrm{NE}$ & Mid & $\begin{array}{l}\text { SW - S - } \\
\text { SE }\end{array}$ & $\begin{array}{l}\text { Average } \\
\text { to High }\end{array}$ & Oct - Mar \\
\hline Ponta Delgada & São Vicente & 5 & Rocks & Left Hand & $N-N W$ & Low - Mid & $\begin{array}{l}\text { SW - S - } \\
\text { SE }\end{array}$ & $\begin{array}{l}\text { Average } \\
\text { to High }\end{array}$ & Sep - May \\
\hline $\begin{array}{l}\text { Praia da Ribeira } \\
\text { (Arco S. Jorge) }\end{array}$ & Santana & 4 & Rocks & Right Hand & $N-N W$ & Mid & SW - S & $\begin{array}{l}\text { Average } \\
\text { to High }\end{array}$ & Oct - Mar \\
\hline $\begin{array}{l}\text { Praia da Rocha do } \\
\text { Navio }\end{array}$ & Santana & 4 & Rocks & Right Hand & $\mathrm{N}-\mathrm{NW}-\mathrm{NE}$ & Mid & SW-S & $\begin{array}{l}\text { Average } \\
\text { to High }\end{array}$ & Oct - Mar \\
\hline $\begin{array}{l}\text { Praia da Ribeira } \\
\text { do Faial }\end{array}$ & Santana & 3 & Rocks & Left Hand & $\mathrm{N}-\mathrm{NW}-\mathrm{NE}$ & Mid & W-SW-s & $\begin{array}{l}\text { Average } \\
\text { to High }\end{array}$ & Oct - Mar \\
\hline $\begin{array}{l}\text { Praia de Dentro } \\
\text { (Porto da Cruz) }\end{array}$ & Machico & 3 & Sand & $\begin{array}{l}\text { Left and } \\
\text { Right Hand }\end{array}$ & $\mathrm{N}-\mathrm{NW}-\mathrm{NE}$ & All Tides & SW-S & High & All year \\
\hline $\begin{array}{l}\text { Praia da Alagoa } \\
\text { (Porto da Cruz) }\end{array}$ & Machico & 3 & Sand & $\begin{array}{l}\text { Left and } \\
\text { Right Hand }\end{array}$ & $\mathrm{N}-\mathrm{NW}-\mathrm{NE}$ & All Tides & SW - S & High & All year \\
\hline $\begin{array}{l}\text { Praia da Enseada } \\
\text { (Porto da Cruz) }\end{array}$ & Machico & 4 & Rocks & Left Hand & $\mathrm{N}-\mathrm{NW}-\mathrm{NE}$ & Low - Mid & SW - S & $\begin{array}{l}\text { Average } \\
\text { to High }\end{array}$ & Sep - May \\
\hline $\begin{array}{l}\text { Praia da Maiata } \\
\text { (Porto da Cruz) }\end{array}$ & Machico & 4 & $\begin{array}{l}\text { Sand and } \\
\text { Rocks }\end{array}$ & $\begin{array}{l}\text { Left and } \\
\text { Right Hand }\end{array}$ & $\mathrm{N}-\mathrm{NW}-\mathrm{NE}$ & All Tides & SW - S & High & All year \\
\hline $\begin{array}{l}\text { Praia das Areias } \\
\text { (Porto da Cruz) }\end{array}$ & Machico & 3 & Sand & $\begin{array}{l}\text { Left and } \\
\text { Right Hand }\end{array}$ & $\mathrm{N}-\mathrm{NW}-\mathrm{NE}$ & All Tides & SW - S & High & All year \\
\hline Prainha (Caniçal) & Machico & 3 & Sand & $\begin{array}{l}\text { Left and } \\
\text { Right Hand }\end{array}$ & NE - E -SE & Low - Mid & $\begin{array}{l}N W-N- \\
N E\end{array}$ & Poor & May - Sep \\
\hline $\begin{array}{l}\text { Ribeira de } \\
\text { Machico }\end{array}$ & Machico & 4 & Rocks & Left Hand & NE - E -SE & Mid - High & $\begin{array}{l}\text { NW - N - } \\
\text { NE }\end{array}$ & $\begin{array}{l}\text { Poor to } \\
\text { Average }\end{array}$ & May - Mar \\
\hline Praia de Machico & Machico & 3 & $\begin{array}{l}\text { Sand and } \\
\text { Rocks }\end{array}$ & $\begin{array}{l}\text { Left and } \\
\text { Right Hand }\end{array}$ & $N E$ - E -SE & All Tides & $\begin{array}{l}\text { NW - N - } \\
\text { NE }\end{array}$ & Average & May - Mar \\
\hline $\begin{array}{l}\text { Ponta dos Reis } \\
\text { Magos }\end{array}$ & Santa Cruz & 3 & Rocks & Left Hand & E - SE & Mid & $N W-N$ & Poor & May - Sep \\
\hline
\end{tabular}


southwest coast, being a business opportunity in other more isolated places, contributing for the development of these localities, such as the north coast of the island.
Nowadays there are 6 surf camps located near other surf spots around Madeira Island: 1 in Ribeira Brava (south coast), 2 in Jardim do Mar (southwest coast), 1 in São Vicente (north

Table 2. Surfers characteristics.

\begin{tabular}{|c|c|c|c|}
\hline Surf Spot & $\begin{array}{l}\text { Surfers Experience } \\
\text { (Good Day) }\end{array}$ & $\begin{array}{l}\text { Surfers Experience } \\
\text { (Average Day) }\end{array}$ & $\begin{array}{l}\text { Crowd } \\
\text { (Freq Surfers) }\end{array}$ \\
\hline Praia Formosa & Experienced Surfers & Experienced to Intermediate Surfers & Some surfers \\
\hline Praia dos Namorados & Experienced Surfers & Intermediate Surfers & Few surfers \\
\hline Pizo/ Ribeira dos Socorridos & Experienced Surfers & Experienced Surfers & Few surfers \\
\hline Cabo Girão & Experienced to Intermediate Surfers & Experienced to Intermediate Surfers & Some surfers \\
\hline Fajã dos Padres & Experienced to Intermediate Surfers & Intermediate Surfers & Few surfers \\
\hline Lugar de Baixo & Experienced Surfers & Experienced to Intermediate Surfers & Crowded \\
\hline Madalena do Mar & Experienced to Intermediate Surfers & Intermediate Surfers & Some surfers \\
\hline Jardim do Mar & Experienced Surfers & Experienced Surfers & Some surfers \\
\hline Ponta Pequena & Experienced Surfers & Experienced to Intermediate Surfers & Some surfers \\
\hline Paúl do Mar & Experienced Surfers & Experienced to Intermediate Surfers & Some surfers \\
\hline Fajã da Galinhas & Experienced Surfers & Experienced Surfers & Few surfers \\
\hline Ponta do Pargo & Experienced Surfers & Experienced Surfers & Few surfers \\
\hline Praia das Achadas da Cruz & Experienced to Intermediate Surfers & Experienced to Intermediate Surfers & Some surfers \\
\hline Ponta do Tristão & Experienced Surfers & Experienced Surfers & Few surfers \\
\hline Lage das Piscinas do Porto Moniz & High Experienced Surfers & High Experienced Surfers & Few surfers \\
\hline Ribeira da Janela & Experienced Surfers & Experienced Surfers & Some surfers \\
\hline Fajã das Contreiras & Experienced Surfers & Experienced Surfers & Some surfers \\
\hline Envelopes (Ribeira Funda) & Experienced Surfers & Experienced to Intermediate Surfers & Few surfers \\
\hline Praia da Jamaica (Seixal) & Experienced Surfers & Experienced to Intermediate Surfers & Few surfers \\
\hline Esquerdas de São Vicente & Experienced to Intermediate Surfers & Experienced to Intermediate Surfers & Crowded \\
\hline Direitas de São Vicente & Experienced to Intermediate Surfers & Experienced to Intermediate Surfers & Some surfers \\
\hline Fajã da Areia (Baía dos Juncos) & Experienced to Intermediate Surfers & Experienced to Intermediate Surfers & Crowded \\
\hline Pico do Manny & High Experienced Surfers & High Experienced Surfers & Few surfers \\
\hline Ponta Delgada & Experienced Surfers & Experienced Surfers & Few surfers \\
\hline Praia da Ribeira (Arco S. Jorge) & Experienced Surfers & Experienced Surfers & Few surfers \\
\hline Praia da Rocha do Navio & Experienced Surfers & Experienced Surfers & Few surfers \\
\hline Praia da Ribeira do Faial & Experienced Surfers & Experienced Surfers & Few surfers \\
\hline Praia de Dentro (Porto da Cruz) & Intermediate Surfers & All surfers & Some surfers \\
\hline Praia da Alagoa (Porto da Cruz) & Intermediate Surfers & All surfers & Crowded \\
\hline Praia da Enseada (Porto da Cruz) & Experienced to Intermediate Surfers & Intermediate Surfers & Some surfers \\
\hline Praia da Maiata (Porto da Cruz) & Experienced to Intermediate Surfers & All surfers & Crowded \\
\hline Praia das Areias (Porto da Cruz) & Experienced to Intermediate Surfers & All surfers & Few surfers \\
\hline Prainha (Caniçal) & All surfers & All surfers & Few surfers \\
\hline Ribeira de Machico & Experienced to Intermediate Surfers & Intermediate Surfers & Crowded \\
\hline Praia de Machico & Intermediate Surfers & All surfers & Crowded \\
\hline Ponta dos Reis Magos & Experienced to Intermediate Surfers & Experienced to Intermediate Surfers & Few surfers \\
\hline
\end{tabular}


coast), and 2 in Porto da Cruz (northeast coast). This allows us to pronounce a huge evolution in the regional surfing tourism scenario (see Table 3).

In the last years, local government and mainly the private sector has executed good strategies for the touristic development of Madeira Region and made good decisions based in well defined targets, which establish the desirable growth boundaries and, at the same time, give local sustainable development.

Praia da Lagoa (Porto da Cruz - Machico municipality) is recommended for beginner surfers or less experienced surfers, as it has a low risk due to the sand bottom. It is due to this fact that the majority of surf schools are located in that area (see Table 3).

Still, three of the most popular surf spots have protective seawalls and promenades. These kinds of constructions, especially located on the south coast of the island, have caused serious wave damage. The surf spots lost some of their world-class qualities. Moreover surfers now face dangerous security issues, when accessing the surf spots during the mid and high tides with high swells. The surf spots are no longer accessible to all levels of experience, and they are recommended only for the most experienced surfers who have the skills and the local knowledge to surf them.

The opinion of the most experienced local surfers is that Madeira Island still has good conditions for surfing, but lost some of the world-class surf spots (Lopes, 2008). They recognize that there are still several surf spots that have not been damaged by the coastline interventions, and continue to present very high quality for adventure surfers.

With regard to touristic promotion of this sport and type of tourism, the most experienced local surfers strongly criticizes local government and regional entities, considering that nothing or very little was done in the past to promote surf tourism. It is also highlighted the need to differentiate the surf spots and the waves according surfers' level of experience, and limit or order access to the amount of tourists and practitioners in order to preserve the quality of the environment surroundings, the natural balance and safety of surf spots. The results also recommend the organization of surfing events / contests, of national and international level, as a source of tourism attraction and also promotion of the image of Madeira Region, targeted only for very specific audiences rather than for a the general public. The experienced local surfers also considered that the actions in the past were still poorly developed aiming the growth and development of surfing in the region. At the time of the first study, in 2009, surfing already had an interesting sports development potential, not only from the involvement of local practitioners point of view, but also in terms of tourist attraction, tourists seeking recreation and adventure.

Nowadays Madeira Island is experiencing an exponential growth of the number of new local surfers, as well as surf tourists. Our suggestions to maintain this growth in a sustainable way are the following: provide better conditions for surf clubs and surf schools for youngsters to have access to surfing; organization of several surfing events / contests that allow surfers to improve surfing skills, also attracting tourists seeking unique experiences, exchange experiences with local surfers; and finally increasing the surf spot offer for all levels of surfing experience (intermediate, experienced and beginners surfers), especially in different locations of the island.

From the strengths point of view, the results point us to the unique and excellent weather conditions, the temperature of the sea and the quality of local surf spots, as well as the hospitality of the residents and security. Weaknesses highlighted the lack of strategic vision of local and regional tourism for the development of the sport and this specific tourism product, although during the last years this has been improving a lot, together with the small number of surf spots suitable for beginners.

The results of this study, also suggest that surfing provides an alternative, successfully limiting the phenomenon of seasonality, which is evident in the colder months, which correspond to the greatest influx of surf tourists / surfers. 
Table 3. Surf spots facilities and access

\begin{tabular}{|c|c|c|c|}
\hline Surf Spot & Accessibility & Surf Camp & Surf School \\
\hline Praia Formosa & $\begin{array}{l}\text { Car Access } \\
\text { (public parking) }\end{array}$ & No & Yes (two) \\
\hline Praia dos Namorados & $\begin{array}{l}\text { Car Access } \\
\text { (public parking) }\end{array}$ & No & No \\
\hline Pizo/ Ribeira dos Socorridos & $\begin{array}{l}\text { Car Access } \\
\text { (no parking) }\end{array}$ & No & No \\
\hline Cabo Girão & Cable-car, Boat access, pathway & No & Yes (one) \\
\hline Fajã dos Padres & Cable-car, Boat access, pathway & Yes (one) & No \\
\hline Lugar de Baixo & $\begin{array}{l}\text { Car Access } \\
\text { (public parking) }\end{array}$ & No & No \\
\hline Madalena do Mar & $\begin{array}{l}\text { Car Access } \\
\text { (public parking) }\end{array}$ & No & No \\
\hline Jardim do Mar & $\begin{array}{l}\text { Car Access } \\
\text { (public parking) }\end{array}$ & Yes (two) & No \\
\hline Ponta Pequena & Boat Access, pathway & No & No \\
\hline Paúl do Mar & $\begin{array}{l}\text { Car Access } \\
\text { (public parking) }\end{array}$ & No & Yes (one) \\
\hline Fajã da Galinhas & Boat Access, pathway & No & No \\
\hline Ponta do Pargo & Boat Access, pathway & No & No \\
\hline Praia das Achadas da Cruz & Cable-car, Boat Access, pathway & No & No \\
\hline Ponta do Tristão & Boat Access, pathway & No & No \\
\hline Lage das Piscinas do Porto Moniz & $\begin{array}{l}\text { Car Access } \\
\text { (public parking) }\end{array}$ & No & No \\
\hline Ribeira da Janela & $\begin{array}{l}\text { Car Access } \\
\text { (no parking, old regional road) }\end{array}$ & No & No \\
\hline Fajã das Contreiras & $\begin{array}{l}\text { Car Access } \\
\text { (no parking, old regional road) }\end{array}$ & No & No \\
\hline Envelopes (Ribeira Funda) & $\begin{array}{l}\text { Car Access } \\
\text { (no parking, old regional road) }\end{array}$ & No & No \\
\hline Praia da Jamaica (Seixal) & $\begin{array}{l}\text { Car Access } \\
\text { (public parking) }\end{array}$ & No & No \\
\hline Esquerdas de São Vicente & $\begin{array}{l}\text { Car Access } \\
\text { (public parking) }\end{array}$ & Yes (one) & Yes (one) \\
\hline Direitas de São Vicente & $\begin{array}{l}\text { Car Access } \\
\text { (public parking) }\end{array}$ & No & No \\
\hline Fajã da Areia (Baía dos Juncos) & $\begin{array}{l}\text { Car Access } \\
\text { (public parking) }\end{array}$ & No & No \\
\hline Pico do Manny & Boat Access & No & No \\
\hline Ponta Delgada & $\begin{array}{l}\text { Car Access } \\
\text { (public parking) }\end{array}$ & No & No \\
\hline Praia da Ribeira (Arco S. Jorge) & $\begin{array}{l}\text { Car Access } \\
\text { (public parking) }\end{array}$ & No & No \\
\hline Praia da Rocha do Navio & Cable-car, Boat Access, pathway & No & No \\
\hline Praia da Ribeira do Faial & $\begin{array}{l}\text { Car Access } \\
\text { (public parking) }\end{array}$ & No & No \\
\hline Praia de Dentro (Porto da Cruz) & Boat Access, pathway & No & No \\
\hline Praia da Alagoa (Porto da Cruz) & $\begin{array}{l}\text { Car Access } \\
\text { (public parking) }\end{array}$ & No & Yes (one) \\
\hline Praia da Enseada (Porto da Cruz) & $\begin{array}{l}\text { Car Access } \\
\text { (public parking) }\end{array}$ & Yes (one) & No \\
\hline Praia da Maiata (Porto da Cruz) & $\begin{array}{l}\text { Car Access } \\
\text { (public parking) }\end{array}$ & Yes (one) & Yes (one) \\
\hline Praia das Areias (Porto da Cruz) & Boat Access, pathway & No & No \\
\hline Prainha (Caniçal) & $\begin{array}{l}\text { Car Access } \\
\text { (public parking) }\end{array}$ & No & No \\
\hline Ribeira de Machico & $\begin{array}{l}\text { Car Access } \\
\text { (public parking) }\end{array}$ & No & No \\
\hline Praia de Machico & $\begin{array}{l}\text { Car Access } \\
\text { (public parking) }\end{array}$ & No & Yes (one) \\
\hline Ponta dos Reis Magos & $\begin{array}{l}\text { Car Access } \\
\text { (public parking) }\end{array}$ & No & No \\
\hline
\end{tabular}


Our study results also allow us to confirm that Madeira's Region possesses several surf spots, with different levels of difficulty (surfing experience), adequate from beginner to advanced surfers. Furthermore, the fact that the location of the island joins unique characteristics, with frequent high swells during the whole year, reduces the phenomenon of seasonality which is very evident in other types of tourism.

As a result of this, a better understanding of surf tourist's choice patterns could benefit both surfers and the tourism industry (that could increase profit by attracting more surf tourists from a particular segment or by higher numbers of repeat visitors). This knowledge can be used in strategic marketing initiatives. A great advantage for these surf spots is that they offer a variety and constant discovery. For this reason, and as opposed to other sport activities, investment in infrastructures by authorities is not required, or doesn't require high levels of maintenance.

Due to the constructions of jetties, seawalls, marinas and promenades, in the previous decade 2000 to 2009, some of Madeira's Island finest quality surf spots were damaged, and also some waves were lost (see Table 4). We also discuss recovering the priority surf spots who lost part of their world class quality, such as Lugar de Baixo (Ponta do Sol municipality), Jardim do Mar (Calheta municipality) and Ponta Delgada (São Vicente municipality), due to not including surfing as part of coastal management, in the past.

Moreover we consider improving the quality and consistency of several surf spots like Praia Formosa and Praia dos Namorados (located in main town - Funchal), Praia da Madalena do Mar (Ponta do Sol municipality), the wave of Ribeira do Faial (Santana municipality), Praia da Enseada (Porto da Cruz municipality) and Ponta dos Reis Magos (Santa Cruz municipality), with the use of artificial MPR (Multi-Purpose Reefs), allowing and increasing the access for surf tourists and young surfers, as well as decentralize the surf spots offer all year long.

The economic value of surfing in Madeira Region has several fundamental aspects, and we develop them in a chronological order: consumption held by surfers and families or viewers; to provide surfboards and surf accessories (surf shops); media promotion created by the spectacular image of surfing in local crystal waters; coastal hostel units (surf camps) occupied by surf tourists and families; tourist and media income generated by surfing events; surf schools as sports and tourism companies; local small factories producing surfboards and surf accessories; and artificial Multi-Purpose Reefs, the structures to create new surf spots and produce economic development, contributing also for costal protection, and avoiding coastal erosion.

In this section of this paper, we only detail the tourist value and industrial value of surfing in Madeira Region. For the tourist value we select only the coastal parishes of the municipality of Calheta (southwest coast), because it was the birthplace of surfing in Madeira Island and this is still the hub of the surf tourism in this region. The existence of three waves / surf spots of top worldwide quality, which is very rare anywhere in the world, namely the wave of Paul do Mar, the wave of Ponta Pequena and the wave of Jardim do Mar, and the sunny climate, natural beauty and the hotel facilities, hotel are the main causes of this surfing pole. For the industrial value we will detail the remaining industries, not accommodation industry, existing in Madeira Island for surfing. We can consider that each wave / surf spot can accommodate in coincidence from 30 to 40 surfers. Whereas each surfer can surf 2 hours per day for one sunny day between $10 \mathrm{~h}$ to $12 \mathrm{~h}$, this corresponds to about 200 per day in a surf spot. We note that Madeira Island, according to Table 1, only for its world class waves can presently accommodate up to 1000 surfers.

Before the decade from 2000 to 2009, when several coastal structures were built, a larger number of waves of global quality existed in Madeira Island. The surf spot of Lugar de Baixo (Ponta do Sol municipality) is still surfed but it lost its world-class quality, and it's more dangerous to surf there. Also the wave of Jardim do Mar (Calheta municipality) remains a world class surf spot although its quality was reduced because it can only be surfed during low tide, due to the loss of area of wave 
Surfing Tourism Plan: Madeira Island Case Study.

Table 4. Surf spots Interventions based on tourist interest.

\begin{tabular}{|c|c|c|c|}
\hline Surf Spot & Touristic Interest & Notes and Specifications & Type of Intervention \\
\hline Praia Formosa & High & $\begin{array}{l}\text { Low consistency wave, shore- } \\
\text { break }\end{array}$ & $\begin{array}{l}\text { Multi-Purpose Reef } \\
\text { (MPR) }\end{array}$ \\
\hline Praia dos Namorados & Mid & $\begin{array}{l}\text { Low consistency wave, shore- } \\
\text { break }\end{array}$ & $\begin{array}{l}\text { Multi-Purpose Reef } \\
\text { (MPR) }\end{array}$ \\
\hline Pizo / Ribeira dos Socorridos & Mid & Lost wave & Repair wave \\
\hline Cabo Girão & Extremely High & Top quality wave & None \\
\hline Fajã dos Padres & High & Top quality wave & None \\
\hline Lugar de Baixo & Extremely High & Damaged wave & Priority repair \\
\hline Madalena do Mar & High & $\begin{array}{l}\text { Low consistency wave, shore- } \\
\text { break }\end{array}$ & $\begin{array}{l}\text { Multi-Purpose Reef } \\
\text { (MPR) }\end{array}$ \\
\hline Jardim do Mar & Extremely High & Damaged wave & Priority repair \\
\hline Ponta Pequena & Extremely High & Top quality wave & None \\
\hline Paúl do Mar & Extremely High & Slightly Damaged wave & None \\
\hline Fajã da Galinhas & Extremely High & Top quality wave & None \\
\hline Ponta do Pargo & Extremely High & Boat access, Top quality wave & None \\
\hline Praia das Achadas da Cruz & Extremely High & Top quality wave & None \\
\hline Ponta do Tristão & Extremely High & Big Wave surfing & None \\
\hline $\begin{array}{l}\text { Lage das Piscinas do Porto } \\
\text { Moniz }\end{array}$ & High & Extreme surfing & None \\
\hline Ribeira da Janela & Extremely High & Top quality wave & $\begin{array}{l}\text { Beach Park and Cliff } \\
\text { Consolidation }\end{array}$ \\
\hline Fajã das Contreiras & Extremely High & Top quality wave & $\begin{array}{l}\text { Beach Park and Cliff } \\
\text { Consolidation }\end{array}$ \\
\hline Envelopes (Ribeira Funda) & Mid & Low consistency wave & $\begin{array}{l}\text { Beach Park and Cliff } \\
\text { Consolidation }\end{array}$ \\
\hline Praia da Jamaica (Seixal) & Mid & Low consistency wave & Beach Park \\
\hline Esquerdas de São Vicente & High & Top quality wave & $\begin{array}{l}\text { Beach Park and Cliff } \\
\text { Consolidation }\end{array}$ \\
\hline Direitas de São Vicente & Mid & $\begin{array}{l}\text { Low consistency wave, shore- } \\
\text { break }\end{array}$ & $\begin{array}{l}\text { Beach Park and Cliff } \\
\text { Consolidation }\end{array}$ \\
\hline Fajã da Areia (Baía dos Juncos) & Extremely High & $\begin{array}{l}\text { Top quality Slightly Damaged } \\
\text { wave }\end{array}$ & Beach Park \\
\hline Pico do Manny & High & $\begin{array}{l}\text { Big Wave surfing } \\
\text { Tow-in wave }\end{array}$ & None \\
\hline Ponta Delgada & Extremely High & $\begin{array}{l}\text { Top quality wave } \\
\text { Lost wave }\end{array}$ & Priority repair \\
\hline Praia da Ribeira (Arco S. Jorge) & High & Low consistency wave & None \\
\hline Praia da Rocha do Navio & Extremely High & Inside Natural Park & None \\
\hline Praia da Ribeira do Faial & High & Damaged wave & $\begin{array}{l}\text { Repair wave and Multi- } \\
\text { Purpose Reef (MPR) }\end{array}$ \\
\hline Praia de Dentro (Porto da Cruz) & Mid & Rock collapse & None \\
\hline Praia da Alagoa (Porto da Cruz) & High & Surf schools & Beach Park \\
\hline $\begin{array}{l}\text { Praia da Enseada (Porto da } \\
\text { Cruz) }\end{array}$ & High & Slightly Damaged wave & $\begin{array}{l}\text { Multi-Purpose Reef } \\
\text { (MPR) }\end{array}$ \\
\hline Praia da Maiata (Porto da Cruz) & Extremely High & Slightly Damaged wave & Beach Park \\
\hline $\begin{array}{l}\text { Praia das Areias (Porto da } \\
\text { Cruz) }\end{array}$ & Mid & Boat access & None \\
\hline Prainha (Caniçal) & Mid & Low consistency wave & None \\
\hline Ribeira de Machico & High & Lost half wave & (Pollution) \\
\hline Praia de Machico & High & Surf schools & (Pollution) \\
\hline Ponta dos Reis Magos & High & $\begin{array}{l}\text { Slightly Damaged wave, pier / } \\
\text { seawall }\end{array}$ & $\begin{array}{l}\text { Multi-Purpose Reef } \\
\text { (MPR) }\end{array}$ \\
\hline
\end{tabular}

breaking between take-off zone (area where the surfer catch the wave) and seawall; moreover the quality of the landscape was severely damaged. The Ponta Delgada (São
Vicente municipality) wave was completely lost its world-class quality, and nowadays is not possible to surf there, because the jetty is in the middle of the surfing zone. Presently in 
Madeira Island the remaining waves / surf spots of global quality are the wave of Paul do Mar, the wave of Ponta Pequena (both in Calheta municipality), the wave of Ribeira da Janela and the wave of Fajã das Contreiras (both in Porto Moniz municipality), the wave of Cabo Girão (Câmara de Lobos municipality), the wave of Fajã dos Padres (Ribeira Brava municipality) and the wave of Achadas da Cruz (also in Porto Moniz municipality).

In Madeira Island, the duration of surfing tourists' visits is on average for one week. We estimate that the expenses per tourist, per week reaches around 1000.00 Euros (including overnight stays, meals, bars and clubs, transport, equipment hire, surf lessons, handicrafts and regional products / cuisine). Thus, we reach three different values, as a result of the coastal planning and its impacts on surfing: before the coastal constructions of the decade from 2000 to 2009, the tourism value of surfing could reach around 10 million Euros per year (during low season) just in the Calheta municipality. After these coastal interventions it decreased to around 2 million Euros per year. If surfing is preserved, and surf spots are recovered and organized events to promote surfing, the touristic value of surfing can reach 50 million Euros per year just in Calheta municipality.

\section{Discussion and Conclusions}

The economic and financial value generated by the surfing industry in Madeira Island is currently expanding. In recent years, surf companies have enhanced the regional economy. These companies pay taxes and create skilled jobs, generating income, contributing to economic growth on the island, and consequently to the increase of regional GDP.

In most cases the emerging surf companies are created by young entrepreneurs. They help to oppose the current economic crisis, both socially and financially. Based on the important natural resources of the island (number and quality of surf spots), new start-ups are investing in the surf economy "niche". Presently, several surf companies are dedicates to surfing in Madeira Island (8 surf schools, 3 surf shops and 1 surfboard factory).
Madeira and Porto Santo are the two main islands of the Region and have amazing and unique conditions, regarded as islands with high quality tourism. They should preserve all their surf spots, in order to offer excellent conditions for local and foreign surfers, satisfying the needs and motivations of surfers as users of these recreational areas / competition.

The existing infrastructures in some surf spots are not yet directed specifically to support surfing, but to the general public and in most cases, are only during the bathing season (May-September). However, a new paradigm has been developing in public sector. From the previous lack of interest in utilizing surfing as a marketing strategy for tourism development, and the absence of specific policies directed towards promoting surfing on the region, presently there is a political strategy concern to recover the image of this world-class surfing region. One of the new main goals consist in restoring previously damaged surf spots. In the same way, the programs in the region for the next years include ocean activities as a priority tourism development strategy. In addition, surfing events are also regarded as important to promote the Region and its municipalities.

Finally in this study, and according to our data, surf tourists appreciate not only the wave quality, but also safety and the quality of services complementary to surfing. Madeira Island offers unique conditions not only for surfing, but also in its climate, environment, safety, healthcare and therefore these are strong points that should be preserved and should be associated the services provided to surfers.

The results of our study also suggest that surfing is an alternative activity to oppose seasonality, in particular during the colder seasons coincide with the largest influx of tourists to practice these surfing activities.

One major issue that local surfers recommend is that surf tourism should aim to maintain the current tourist capacity of the region, and not in increasing its capacity. One of the most important attractive points of Madeira Island is its uncrowned surf spots. It is thus crucial to 
preserve the coastal environment with a sustainable development of the regional coastline.

Ideally, the coastline should be evaluated and planned within the framework of an integrated plan for surfing, including surf reserves. The surf reserves should consider legal sanctions to preserve the environment of the surf spots and their surroundings.

In addition, as a result of our study, we are now able to provide detailed recommendations for the sustainable development in the surf tourism in Madeira Island. We hope our study will play an effective role in the assessment of future possible alternatives for coastal development and to select from these alternatives the one with the best benefit / cost ratio.

\section{References}

Borne, G. (2014). Sustainability Surfing. Huffington Post. URL: http://www.huffingtonpost.co.uk/gregoryborne/sustainability-surfing_b_4743397.html (Accessed on 07 February 2014)

Bicudo, P., Horta, A. (2009). Integrating Surfing in the Socio-economic and Morphology and Coastal Dynamic Impacts of the Environmental Evaluation of Coastal Projects, International Coastal Symposium, Journal of Coastal Research.SI 56, 11151119.

Buckley, R. (2002). Surf Tourism and Sustainable Development in Indo-Pacific Islands. Journal of Sustainable Tourism, 10 (5), 405-442.

EuroSIMA (2014). EuroSIMA Activity Report 2013-2014. URL: http://issuu.com/eurosima/docs/rapport2014-eng (Accessed on 16.12.2014)

Ferrony, R., Lopes, J., Bicudo, P. (2013). Surfing Evolution in Portugal in the Last Decade. 2th International Congress of Sports and Ocean. Funchal. Portugal.
Fluker, M. (2003). Riding The Wave: Defining Surf Tourism. Amalgamates Solutions and Research.

URL: http://www.asrltd.co.nz/downloads/Reefs/re ef $\% 20$ economics/CAUTHE\%20def\%20surf \%20tsm.pdf (Accessed on 16.12.2010)

Fluker, M., Dolnicar, S. (2003). Behavioural Market Segments Among Surf Tourists: Investigating Past Destination Choice. Journal of Sport Tourism, 8 (3), 186-196.

FPS (2008). Official website of the Portuguese Federation of Surfing. URL: http://www.surfingportugal.com/

Horta, A., Bicudo, P. (2009). Surf and the Socio-Economics Factor of Environmental Assessment of Costal Projects Portuguese Case Study. Presented at IMPR2009, The Reef Journal. Volume 2: 2012. Editors: J.C. Borrero and D.J. Phillips. 2009.

URL: http://www.thereefjournal.com/files/Reef_Jo urnal_2012 final_101212.pdf (Accessed on 16.12.2014)

Lopes, J. (2008). Surf and Bodyboard as Touristic Products of the Autonomous Region of Madeira (MSc Dissertation). Madeira University (in Portuguese).

SOS (2008). Unpublished SOS Salvem O Surf Study of the endangered surf waves in Portugal (in Portuguese). URL: http://pt.slideshare.net/mpreto/eshte-sossalvem-o-surf-maio11 (Accessed on 16.12.2014)

SOS (2014). SOS Salvem O Surf Study of endangered surf spots in Madeira and Porto Santo Islands. Paper presented in II Desporto e Mar $1^{\text {st }} 3^{\text {th }}$ November 2013. Clube Naval do Funchal. Madeira Island, Portugal.

URL: http://www.clubenavaldofunchal.com/Admi n/Public/DWSDownload.aspx?File $=\% 2 \mathrm{fFil}$ es $\% 2$ fFiler\%2fCongresso+Desporto+e+o+ Mar+2014\%2fLivro\%2fLivro_Desafios_e_ Oportunidades_na_Madeira.pdf (Accessed on 16.12.2014). 